\title{
Tyrosine-Protein Kinase Transmembrane Receptor ROR1
}

National Cancer Institute

\section{Source}

National Cancer Institute. Tyrosine-Protein Kinase Transmembrane Receptor ROR1. NCI

Thesaurus. Code C29879.

Tyrosine-protein kinase transmembrane receptor ROR1 (937 aa, 104 kDa) is encoded

by the human ROR1 gene. This protein plays a role in receptor type tyrosine kinase-

mediated signaling. 